\title{
CrimRxiv
}

\section{International approaches to rape}

Nicole Westmarland, Geetanjali Gangoli

Published on: Jul 01, 2011

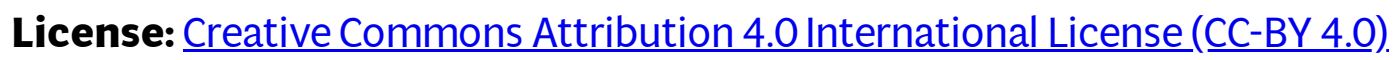


